\title{
Editorial: Towards the Sustainable Use of African Wetlands
}

\author{
John P. Simaika ${ }^{1,2 *}$, Albert Chakona ${ }^{3}$ and Anne A. van Dam ${ }^{1}$ \\ ${ }^{1}$ Department of Water Resources and Ecosystems, IHE Delft Institute for Water Education, Delft, Netherlands, ${ }^{2}$ Department of Soil \\ Science, Stellenbosch University, Stellenbosch, South Africa, ${ }^{3}$ National Research Foundation (NRF)-South African Institute for \\ Aquatic Biodiversity, Makhanda, South Africa
}

Keywords: Africa, wetland, river, freshwater, aquatic ecosystem, sustainability, ecosystem service

\section{Editorial on the Research Topic}

\section{Towards the Sustainable Use of African Wetlands}

The world's wetlands are hanging on to a thinning lifeline, with only $13 \%$ of their former extent remaining (Gardner and Finlayson, 2018). Wetlands in Africa probably conform to this picture, but data on trends in African wetland extent is limited (Davidson, 2014). Some indicators suggest increasing pressure on African wetlands since the 1990s, such as the decreasing WET Index (UN WCMC, 2017) and the threat status of wetland-dependent species in Africa (Gardner and Finlayson, 2018). Major threats include the development of hydropower dams, with some 200 new projects planned in Sub-Saharan Africa (Zarfl et al., 2015), continuing population growth and agricultural and urban development (Beuel et al., 2016; OECD-FAO, 2016). African wetlands are important for their global contribution to ecosystem services on which hundreds of millions of rural communities depend directly for their livelihoods (Dixon and Wood, 2003; Rebelo et al., 2010). Increasingly, the essential role of wetlands in climate change mitigation is recognized (Moomaw et al., 2018), and African countries have made remarkable progress with developing policies for wetland conservation and management. Fifty African nations are signatories to the Ramsar Convention on Wetlands, with 415 Ramsar sites (www.ramsar.org, Access date 22.01.2021). Nevertheless, implementing wise-use strategies remains challenging due to a lack of capacity for policy implementation (Ostrovskaya et al., 2013), and knowledge gaps with respect to wise-use. African countries are looking for a sustainable pathway between wetland development, for sustaining the livelihoods of millions of people; and wetlands conservation, to maintain ecosystem service and biodiversity values of wetlands (Wood et al., 2013). This Research Topic brings together contributions on their geomorphological classification, biological diversity, and ecological functioning, all relevant to the management of African wetlands.

One of the prerequisites of adequate wetland management policies is knowledge of the extent and status of wetlands in a country. Wetland inventories in Africa are often incomplete and monitoring is rare. Stephenson et al. suggest that barriers to effective monitoring range from data availability and quality to willingness and capacity to use monitoring data. They conclude that application of common, policy-relevant indicators, scaling up of traditional and appropriate new tools and protocols, and capacity and partnership building are the main tasks ahead.

Wetland management is often hindered by a lack of dedicated expertize, and declining funds. In a new cost-saving approach, Job et al. did a first full wetland inventory of Mountain Zebra National Park (South Africa) using existing data, imagery, and a participatory approach to select a subset of target sites to assess wetland condition. Significantly, none of the target sites were National Freshwater Ecosystem Priority Areas, highlighting the importance of the participatory approach. Wetland classification in South Africa emphasizes the landscape setting of wetlands as a basis for classification. Grenfell et al. propose to include the geomorphic processes of wetland formation in a new genetic geomorphic

Front. Environ Sci $9: 658$ doi: 10.3389/fenvs.2021.658871 

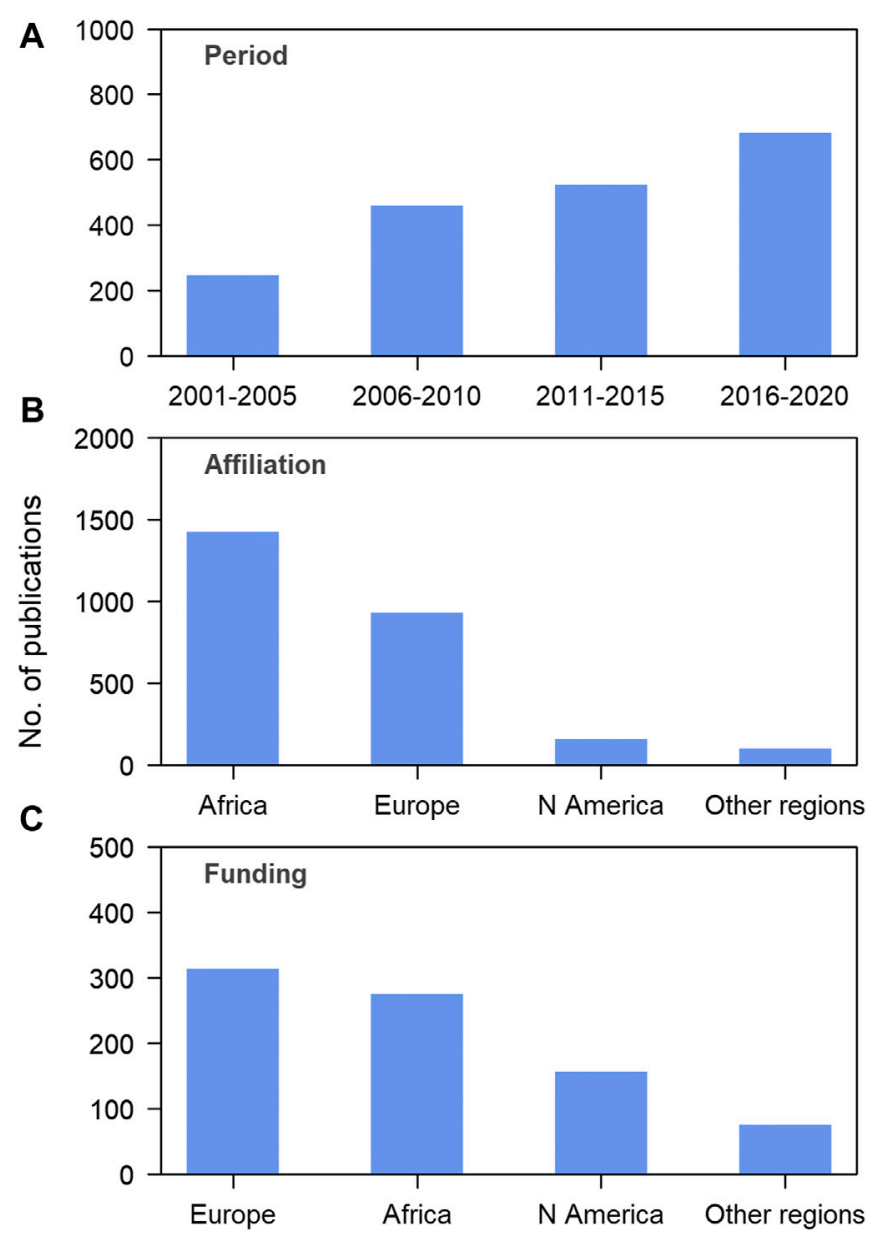

FIGURE 1 | Bar charts of Scopus (www.scopus.com) search results for 'Africa' and 'wetland' in title, abstract and keywords of published articles from 1999 to 2020 (Search date: 12.01.2021). (A) Publications on African wetlands over four 5-year periods (2001-2005; 2006-2010; 2011-2015; 2016-2020); (B) Affiliations associated with research on African wetlands categorized by world region; (C) Funding for research on African wetlands categorized by region.

classification system. Accordingly, the first level of the hierarchical classification considers the sediment source responsible for wetland formation, followed by the wetland type. This approach could be extended to include all wetlands and be used complementary to existing classifications. Mapping and accurately predicting wetland occurrence and extent, hydrogeomorphic (HGM) type, and ecological condition from remote sensing data remains challenging. In a case study of wetlands in the Western Cape (South Africa), Rivers-Moore et al. used a Bayesian model approach to predict hydrogeomorphic types. Four variables, groundwater depth, relief ratio, slope, and elevation were particularly important in building accurate models.

The linear nature of rivers makes the protection of many species difficult, as multiple stressors are added along the river continuum. In an analysis for the Cape Fold Ecoregion (South Africa), Jordaan el al. evaluated the protection of freshwater fishes under the existing protected area network. The results are sobering: the majority of freshwater fish species are inadequately protected. Increasingly, non-invasive sampling methods are gaining importance for monitoring freshwater fish. Castañeda et al. explored three methods for their strengths and weaknesses in the Eastern Cape (South Africa). The detection probability using visual observation methods, snorkel surveys and underwater camera trapping, were compared to environmental DNA (eDNA) sampling. In this study, the traditional visual survey methods were more efficient at detecting target species than the novel sampling method. Tropical, large shallow lakes are highly productive ecosystems. In order to manage these types of lakes both for species conservation and for inland fisheries, it is important to understand how the lake food webs respond to seasonal flooding and drying. For Lake Liambezi in Namibia, Peel et al. identified three major pelagic food chains, two benthic based, and one phytoplankton-based. The latter was the longest food-chain, involving four trophic transfers. Restoring this food chain would lend stability to the ecosystem, in which the tilapiine fishery collapsed in 2016.

Namaalwa et al. investigated the impact of surface water nutrient pollution from agriculture and urbanization on water quality and nutrient and sediment retention in the downstream 
Namatala Wetland (Uganda). Nutrient concentrations were significantly higher in the urbanized streams upstream of the wetland than in the rural streams draining agriculture. The wetland did retain nutrients and sediment in the downstream part, which had more intact papyrus and lateral connectivity. Sileshi et al. investigated the potential of three natural riverine wetlands to retain pollutants and to improve water quality downstream in Jimma Town (Ethiopia). The wetlands did indeed retain pollutants, but this negatively affected the ecological integrity of the wetlands themselves. This finding highlights that water quality needs to be managed to the point that the receiving wetlands are not damaged and can effectively mitigate pollution. A second study on wetland sediment and nutrient retention also in Jimma Town by Mereta et al., supports the findings by Sileshi et al.

The idea that wetlands are converted for agriculture or human settlement mainly because they are perceived as wastelands is brought into question by the fact that despite increased awareness of the importance and value of wetlands, the habitats are continually degraded and lost. In their work on Anyiko wetland (Kenya), Ondiek et al. found that the conversion of the wetland was dependent on the socioeconomic standing of households and not perception of value. Ondiek et al. suggest that a shift in the institutional regulatory framework is needed towards intersectoral collaboration and incentivization for wetland restoration. Also at Anyiko wetland, Owino et al. assessed greenhouse gas emissions from rice paddies with and without fertilizer application. Fertilization had no effect on methane or carbon dioxide emissions, but caused substantial increase in nitrous oxide emissions. Overall the study suggests that cultivation and land preparation is responsible for a loss of organic carbon, limiting the ability of the wetland to store carbon.

The water resource potential of the ephemeral Mara river system (Kenya) was explored by Wekesa et al. Although subject to losses through evapotranspiration and seepage, ephemeral rivers store significant amounts of water in the river alluvium beneath the channel bed. The authors conclude that the annual storage volume could be used as an alternative water source for communities. Whilst this could indeed be done, the current water need for livestock in the catchment already exceeds the available water storage, and would mean that no water would remain for natural fauna or flora.

The submissions to this inter- and multidisciplinary Research Topic present a wide range of research topics on African wetlands, all highly relevant to policy and management for sustainable management, such as traditional and novel monitoring methods, climate change mitigation, and water quality and quantity regulation. The number of scientific

\section{REFERENCES}

Beuel, S., Alvarez, M., Amler, E., Behn, K., Kotze, D., Kreye, C., et al. (2016). A rapid assessment of anthropogenic disturbances in East African wetlands. Ecol. Indicators 67, 684-692. doi:10.1016/j.ecolind.2016. 03.034 publications on African wetlands has risen in the last 2 decades, with a strong involvement of European researchers and funding (Figure 1). Data on wetland loss in tropical Africa is scarce (Davidson, 2014), but it seems reasonable to assume that the degree of forest and river degradation is still lower than in other parts of the world (Döll et al., 2009; Hill et al., 2019). We think that Africa can still aim for a development trajectory towards sustainable catchment management and wise use of wetlands straight away without first losing wetland ecosystem services and then having to restore them in the future, as in Europe and North America (Szałkiewicz et al., 2018). To achieve this, a major effort should go, besides the traditional conservation of protected wetlands, into strengthening integrated landscape management and sustainable agriculture and urbanization (UNCCD, 2017). With respect to research, topics not presented in this Research Topic will need more attention: adaptive governance and the roles of formal and informal institutions (McCartney et al., 2011), participation of local communities in protecting wetlands (Wood et al., 2013), ecosystem services trade-offs at the landscape level (Carpenter et al., 2009; Wangai et al., 2016; Langan et al., 2018), incentivizing conservation (Seidl et al., 2020), conservation psychology (Clayton and Brooks 2005), and economic instruments to support conservation and wise use (ten Brink and Russi, 2018).

\section{DEDICATION}

This Research Topic is dedicated to two of our colleagues who contributed enormously to the conservation of African wetlands: the late Prof. Olaf Weyl, Chief Scientist at the South African Institute for Aquatic Biodiversity and DST/NRF research Chair in Inland Fisheries and Freshwater Ecology; and the late Mr. Paul Mafabi of the Wetlands Inspection Division, later Director of Environment at the Ministry of Water and Environment, Uganda and Chair of the Standing Committee of the Ramsar Convention in 2006-2008.

\section{AUTHOR CONTRIBUTIONS}

JS and AvD drafted the manuscript. All authors reviewed and contributed to the final version of the manuscript.

\section{ACKNOWLEDGMENTS}

We would like to thank the reviewers who volunteered their time and effort in contributing to this Research Topic.

Carpenter, S. R., Mooney, H. A., Agard, J., Capistrano, D., DeFries, R. S., Díaz, S., et al. (2009). Science for managing ecosystem services: beyond the Millennium Ecosystem Assessment. Proc. Natl. Acad. Sci. USA 106, 1305-1312. doi:10.1073/ pnas.0808772106

Clayton, S., and Brook, A. (2005). Can psychology help save the world? A model for conservation psychology. Anal. Soc. Iss. Publ. Pol. 5, 87-102. doi:10.1111/j. 1530-2415.2005.00057.x 
Davidson, N. C. (2014). How much wetland has the world lost? Long-term and recent trends in global wetland area. Mar. Freshw. Res. 65, 934-941. doi:10. $1071 / \mathrm{mf} 14173$

Dixon, A. B., and Wood, A. P. (2003). Wetland cultivation and hydrological management in eastern Africa: matching community and hydrological needs through sustainable wetland use. Nat. Resour. Forum 27, 117-129. doi:10.1111/ 1477-8947.00047

Döll, P., Fiedler, K., and Zhang, J. (2009). Global-scale analysis of river flow alterations due to water withdrawals and reservoirs. Hydrol. Earth Syst. Sci. 13 (12), 2413-2432. doi:10.5194/hess-13-2413-2009

Gardner, R. C., and Finlayson, C. (2018). Global Wetland outlook: state of the World's Wetlands and their services to people. Ramsar Convention Secretariat. Stetson University College of Law Research Paper No. 2020-5. Available at SSRN: https://ssrn.com/abstract=3261606.

Hill, S. L., Arnell, A., Maney, C., Butchart, S. H., Hilton-Taylor, C., Ciciarelli, C., et al. (2019). Measuring forest biodiversity status and changes globally. Front. Forests Glob. Change 2, 70. doi:10.3389/ffgc.2019.00070

Langan, C., Farmer, J., Rivington, M., and Smith, J. U. (2018). Tropical wetland ecosystem service assessments in East Africa: a review of approaches and challenges. Environ. Model. Softw. 102. 260-273. doi:10.1016/j.envsoft.2018. 01.022

McCartney, M., Rebelo, L. M., Mapedza, E., de Silva, S., and Finlayson, C. M. (2011). The Lukanga Swamps: use, conflicts, and management. J. Int. Wildl. Law Policy 14, 293-310. doi:10.1016/j.envsci.2012.12.006

Moomaw, W. R., Chmura, G. L., Davies, G. T., Finlayson, C. M., Middleton, B. A., Natali, S. M., et al. (2018). Wetlands in a changing climate: science, policy and management. Wetlands 38, 183-205. doi:10.1007/s13157-0181023-8

OECD/FAO. (2016). Agriculture in Sub-Saharan Africa: prospects and challenges for the next decade. OECD-FAO agricultural outlook 2016-2025. Paris: OECD Publishing.

Ostrovskaya, E., Douven, W., Schwartz, K., Pataki, B., Mukuyu, P., and Kaggwa, R. C. (2013). Capacity for sustainable management of wetlands: Lessons from the WETwin project. Environ. Sci. Policy 34, 128-137. doi:10.1016/j.envsci.2012. 08.006
Rebelo, L.-M., McCartney, M. P., and Finlayson, C. M. (2010). Wetlands of SubSaharan Africa: distribution and contribution of agriculture to livelihoods. Wetlands Ecol. Manage 18, 557-572. doi:10.1007/s11273-009-9142-x

Seidl, A., Mulungu, K., Arlaud, M., van den Heuvel, O., and Riva, M. (2020). Finance for nature: a global estimate of public biodiversity investments. Ecosyst. Serv. 46, 101216. doi:10.1016/j.ecoser.2020.101216

Szałkiewicz, E., Jusik, S., and Grygoruk, M. (2018). Status of and perspectives on river restoration in Europe: 310,000 Euros per hectare of restored river. Sustainability 10 (1), 129. doi:10.3390/su10010129

ten Brink, P., and Russi, D. (2018). "Economic instruments to respond to the multiple values of wetlands. Ch. 290 (p. 2141-2148)," in The Wetland Book I: wetland structure and function, management, and methods. Editors C. M. Finlayson, M. Everard, K. Irvine, R. McInnes, B. Middleton, A. A. van Dam, et al. Dordrecht, Netherlands: Springer. doi:10.1007/978-90-481-9659-3_299

UNCCD (2017). The global land outlook. 1st edition.

UN WCMC (2017). Wetland Extent Trends [WET] Index. Cambridge, UK.

Wangai, P. W., Burkhard, B., and Müller, F. (2016). A review of studies on ecosystem services in Africa. Int. J. Sustain. Built Environ. 5 (2), 225-245. doi:10.1016/j.ijsbe.2016.08.005

A. Wood, A. Dixon, and M. McCartney (2013). Wetland management and sustainable livelihoods in Africa. London, UK: Routledge.

Zarfl, C., Lumsdon, A. E., Berlekamp, J., Tydecks, L., and Tockner, K. (2015). A global boom in hydropower dam construction. Aquat. Sci. 77, 161-170. doi:10. 1007/s00027-014-0377-0

Conflict of Interest: The authors declare that the research was conducted in the absence of any commercial or financial relationships that could be construed as a potential conflict of interest.

Copyright (c) 2021 Simaika, Chakona and van Dam. This is an open-access article distributed under the terms of the Creative Commons Attribution License (CC BY). The use, distribution or reproduction in other forums is permitted, provided the original author(s) and the copyright owner(s) are credited and that the original publication in this journal is cited, in accordance with accepted academic practice. No use, distribution or reproduction is permitted which does not comply with these terms. 